\title{
Jesus: Divine relationality and suffering creation
}

\begin{tabular}{|c|c|}
\hline \multicolumn{2}{|c|}{$\begin{array}{l}\text { Authors: } \\
\text { Annelien C. Rabie-Boshoff }{ }^{1} \text { (D) } \\
\text { Johan Buitendag }{ }^{1} \text { (D) }\end{array}$} \\
\hline \multicolumn{2}{|c|}{$\begin{array}{l}\text { Affiliation: } \\
{ }^{1} \text { Department of Systema } \\
\text { and Historical Theology, } \\
\text { Faculty of Theology and } \\
\text { Religion, University of } \\
\text { Pretoria, Pretoria, } \\
\text { South Africa }\end{array}$} \\
\hline \multicolumn{2}{|c|}{$\begin{array}{l}\text { Research Project Registration: } \\
\text { Project Leader: J. Buitendag } \\
\text { Project Number: } 02402343\end{array}$} \\
\hline \multicolumn{2}{|c|}{$\begin{array}{l}\text { Description: } \\
\text { This research is part of th } \\
\text { project, 'Theology and } \\
\text { Nature', directed by Prof. } \\
\text { Dr Johan Buitendag, } \\
\text { Department of Systemati } \\
\text { and Historical Theology, } \\
\text { Faculty of Theology and } \\
\text { Religion, University of } \\
\text { Pretoria. }\end{array}$} \\
\hline \multicolumn{2}{|c|}{$\begin{array}{l}\text { Corresponding author: } \\
\text { Johan Buitendag, } \\
\text { johan.buitendag@tuks.co.za; } \\
\text { 1jbuiten@gmail.com }\end{array}$} \\
\hline \multicolumn{2}{|c|}{$\begin{array}{l}\text { Dates: } \\
\text { Received: } 16 \text { May } 2020 \\
\text { Accepted: } 07 \text { July } 2020 \\
\text { Published: } 22 \text { Sept. } 2020\end{array}$} \\
\hline \multicolumn{2}{|c|}{$\begin{array}{l}\text { How to cite this article: } \\
\text { Rabie-Boshoff, A.C., \& } \\
\text { Buitendag, J., 2020, 'Jesus: } \\
\text { Divine relationality and } \\
\text { suffering creation', HTS } \\
\text { Teologiese Studies/ } \\
\text { Theological Studies 76(1), } \\
\text { a6128. https://doi.org/ } \\
\text { 10.4102/hts.v76i1.6128 }\end{array}$} \\
\hline \multicolumn{2}{|c|}{$\begin{array}{l}\text { Copyright: } \\
\text { (C) 2020. The Authors. } \\
\text { Licensee: AOSIS. This } \\
\text { work is licensed under } \\
\text { the Creative Commons } \\
\text { Attribution License. }\end{array}$} \\
\hline \multicolumn{2}{|l|}{ Read online: } \\
\hline 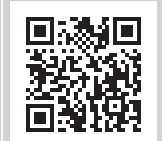 & $\begin{array}{l}\text { Scan this QR } \\
\text { code with your } \\
\text { smart phone or } \\
\text { mobile device } \\
\text { to read online. }\end{array}$ \\
\hline
\end{tabular}

The basic challenge that readers of the New Testament face is not only about what Jesus Christ teaches but who he is. Functional Christology has developed at the expense of ontological Christology. This challenge centres on Jesus Christ's relevance, in terms of his identity, not only for Christians in particular but also for creation as a whole. The question 'who is Jesus Christ in relation to creation?' is thus of special interest to this study. Various authors such as Gunton, Gregersen, Peacocke and others have approached this question from different perspectives. The PhD study by Rabie-Boshoff was completed to shed light into the context of dialogue between Christian theology and the science of linguistics in an effort to understand the Genesis 1 creation story. This article refers to part of the study in an effort to make sense of who Jesus Christ is in relation to creation. This provides consolation in a time of worldwide lockdown because of the Coronavirus Disease 2019 (COVID-19) virus. The human struggle of making sense of the world is brought into sharp focus in times like these, more so in terms of making sense of their creatureliness and mortality. Although science as a valid knowledge base may provide some answers to this human dilemma, Christians in particular appeal to the Bible and their belief in Jesus Christ. This turn to Jesus, and who he is, provides human beings with enduring and satisfying answers to their suffering and pain.

Contribution: This article is an attempt to contribute to the ongoing discussion on creation in terms of how human beings make sense of creation, considering who Jesus Christ is in relation to creation. Human beings have always been engaged in a process of making sense of the world they live in. Ancient cultures provide such a window, allowing a glimpse into how those cultures perceived their world.

Keywords: Systematic theology; Ethics; Ecology; Environment; Cosmic Christ.

\section{Introduction ${ }^{1}$}

'Creation Untamed' - this is an apt phrase in the title of a book written by Terence Fretheim about dealing with natural disasters and the big questions people ask when affected by disastrous events in life. In times of great distress, human beings are faced with the challenge of trying to make sense of what is happening to them and the world they live in, but more so to understand how they relate to a world that seemingly has turned 'wild' on them. By implication it entails making sense of the reality of their own creatureliness as well as coming to an understanding of and acknowledging their creaturely mortality. The pressing issue, however, is not so much about the self as it is about God and how God relates to a seemingly 'wild, untamed' creation. This causes a fundamental tension, which Kaufman (2000) views as a conceptual and logical incompatibility between:

$[O] n$ the one hand, the understanding of God, and of the intimate relation of humanity to God (as seen in our western religious and philosophical traditions), and on the other hand, the growing awareness on the part of human beings that their existence is essentially constituted by, and could never exist apart from, the complex ecological ordering of life that has evolved on planet Earth over many millennia. (p. 4)

This article is an attempt to contribute to the ongoing discussion on creation in terms of how human beings make sense of creation, considering who Jesus Christ is in relation to creation. Following this, the key question is how human beings should speak of Jesus Christ:

$[A]$ s the one 'by [whom] all things were created' (John 1, 2; Colossians 1:16), and 'in [whom] all things hold together' (Colossians 1:17) - in relation to creation, and the suffering and death related hereto?

1.This article represents a reworking of a section from the PhD dissertation by Rev. Dr Annelien Rabie-Boshoff, Dogmatics and Christian Ethics at the University of Pretoria, with the title 'Seeing God in creation: A visio-spatial interpretation of Genesis 1', under the supervision of Prof. Dr Johan Buitendag and Dr Linzay Rinquest as co-promoter. 


\section{Making sense}

Since time immemorial, human beings have been engaged in a process of making sense of the world they live in. The mythologies of ancient cultures like those of the Babylonians and the Egyptians provide a window into the ancient Near Eastern world, allowing a glimpse into how those cultures perceived their world. John Walton (2009:14), for example, sheds light by explaining that mythology 'by its nature seeks to explain how the world works, and how it came to work that way'. Mythologies thus functioned as conduits through which ancient people expressed their beliefs of 'what made the world work', which according to Walton (2009:15) included 'their theories of origins and how the world worked'. In comparison, Walton suggests that science in a certain sense represents a modern mythology as it provides explanations of how the world originated. Moreover, today science provides a particular view on the world and reflects a general consensus of how things work in this world. Although many human beings appeal to science for explanations to unexplained, threatening natural phenomena, Christians in particular appeal to the Bible and their belief in the risen Christ in times of duress. In contrast to ancient mythologies in which gods were believed to be involved and active in the world of humans, science on the other hand works from the premise that God should not be invoked in its overall mode of explanation. The current Coronavirus Disease 2019 (COVID-19) pandemic illustrates this very well. Is this the result of the sins of humans and subsequently God's punishment, asks Chris de Wet (2020) in a recent article on LitNet? ${ }^{2}$

As science eclipsed the humanities and social sciences after the Enlightenment, a misconception took hold of people's minds that science was the only valid knowledge base. Despite differences of opinion, both science and theology are deemed valid knowledge-seeking disciplines and should be defended as such - in Gilkey's (1993:9) words, both are 'necessary for [this] life and for each other'. Early in the 1990s, Arthur Peacocke (1984:4), for one, pointed out that both science and theology 'share alike the tools of groping humanity' - in other words, those words, ideas and images that are handed down through generations, which people then reappropriate within their particular contexts. Alister McGrath deftly draws both science and theology together in his argument that human beings, having been created in God's image, have been created 'with the capacity to make sense of God's creation' (McGrath 2011:2). He thus sees the rise of the natural sciences as a reflection of 'a fundamental human longing to make sense of [their] observations of the natural world'.

Human beings as embodied creatures are intrinsically part of the natural world, both as inhabitants and as observers. Thus, making sense of the world through the acquisition of certain knowledge, either through experiment or experience, requires them to engage their world through a process of actively establishing links that relate their lives to the world they live in. 'The naturalness of humankind implies, by definition, an engagement with nature by means of a specific observation (discernment)' (Buitendag 2009:515). The forging of these relational links between human and world basically happens through the human perceptual system and is fundamental to the process by which insight and understanding of the world are gained, and the ultimate establishment of meaning (Hefner 2006:563). Buitendag (2009) continues in this vein by saying, however:

[N]ature cannot be observed as such, but has always to be observed as something. Consequently, there is no transcendent reality above, behind or in front of the observable, but rather a transcendent reality in the relationship that man has with nature. When interpreted correctly, nature therefore becomes Creation to the faithful. (p. 515)

Human perception is never objective, but as an embrained process allows humans to subjectively experience their world (Collicutt 2008:84; Solms \& Turnbull 2002:77). In and by itself it is, however, not enough to see the world in a particular way. For this, discernment is a crucial requirement. Hefner (2006:566), for example, is adamant that it is fundamental to the process of establishing meaning and points out that this aspect is not 'often cited as a constituent of religion and science'. For Hefner one of the characteristics of discernment is that it is '... an embodied process of knowing and judging'.

\section{Relation in creation}

Western culture views the physical and the spiritual worlds as two distinct realms, mutually exclusive of each other. From a psychological perspective, Collicutt (2008:81) points out that human beings as embodied and embrained creatures can use their knowledge of the natural world to enable them to transcend some of the limitations nature 'would otherwise impose on them'. Although they can access the transcendent through their functional cognitive and perceptual systems, Collicutt (2008:82-83) concedes that these human faculties in themselves are not enough to allow humans to see the natural world in a particular way. This resonates with Hefner's belief that discernment is a prerequisite for humans to establish meaning in their lives (cf. Buitendag 2009:515). As a result of this deepening understanding of human cognition brought about by psychological insights, a bigger picture has been emerging over a number of years within a theological context. McGrath (2008:11), for example, highlights that the JudeoChristian accounts of human engagement with the world point to the fact that humans in fact do actively construct 'a vision of reality', which for him 'is consistent with a "critical realist" epistemology'. Buitendag (2009) believes that this affirms the 'existence of an extra-mental reality' and the fact that humans do indeed engage this reality in an active and constructive manner:

A theology of nature, therefore, amounts to the human perception of nature, as it is shaped through a specific lens. Due to the involvement of the total human being, such a lens is consciously and subconsciously shaped within a bio-cultural framework, in which human experience and imagination play a significant role. (p. 517) 
Since early times Christians have wrestled with making sense of the world - in Wegter-McNelly's (2011:1) words, 'with the idea [of] creation's "otherness"'. The first creation story in the Bible offers a unique glimpse into how the ancient Jewish people made sense of their world. Rabie-Boshoff's (2016) PhD study on Genesis 1 suggests looking at the picture of the created world presented therein from a different perspective in an effort to understand what the story narrates to its readers. By applying the divine sign language (DSL) model that was developed as an interpretive tool for the purpose of the study, a complex network of interrelated patterns was identified in the first creation story (Rabie-Boshoff 2016:111-133). The relational patterns identified within Genesis 1 challenge one to look at the world and see (discern) it in a different way - to discern '... creation as encapsulating [a] deeper relational structure, which embodies a deeper meaning within which the transcendent can be discerned' (Rabie-Boshoff 2016:348). The human person possesses an ex-naturality, which overcomes any neurogenetic determinism.

In a more concrete way, the thesis that creation is characterised by a complex system of relationships is wholly supported by science in all its facets. Terms like for example 'relational biology' and 'relational ecology' are commonly used in the domain of science. Similar terminology is even found to describe reality right down to the level of the quantum world - in Laudisa and Rovelli's (2013:n.p.) words, relational quantum mechanics describe 'the way systems affect one another in the course of physical interactions'.

In the context of science, Hungarian chemist Michael Polanyi's (1967:24) work on the pursuit of discovery supports the notion that human beings are 'guided by sensing the presence of a hidden reality toward which [their] clues are pointing'. McGrath (2011:23), referring to these clues as 'patterns', believes that these clues point to that 'deeper structure, which makes sense of [human] observations and experiences of the world'. He justifies this statement by adding that they are 'not hard proofs, but soft pointers' (McGrath 2011:23), which human beings are able to discern in nature, and which are laden with 'significance and meaning' (McGrath 2009:3). The perception is also personal, in terms of its expressing the unique 'bio-cultural paradigm' (Gregersen 2000:7).

Despite some serious objections from various groupings, religion on the other hand does fulfil an essential role in human beings' quest for meaning. It provides clues of a different, yet equally important kind that also point to a hidden reality, albeit not in the same category as described by science. James (1956:51), for example, speaking of 'riddles', supports this notion by writing that '[r]eligious faith is faith in the existence of an unseen order of some kind in which the riddles of the natural order may be found and explained'. In the context of Genesis 1, Rabie-Boshoff (2016:348) posits that the interrelated patterns identified in the first creation story may very well be those clues, or patterns, or even the riddles these scholars refer to, that point to some deeper structure, some 'hidden reality' that needs to be discovered to find the meaning in life.

Francis Schaeffer $(1972: 47,48)$, starting with the first creation story, applies the imago Dei image in Genesis 1:28 as basis for understanding God's relational character. Based on this, he thus reasons that human beings, having been created in God's image, are therefore also relational creatures, standing in a personal relationship with God and with one another. Duval and Hays, having taken up the theme of relationality in their book, God's Relational Presence (2019), present the thesis that God's relational presence forms the cohesive centre around which the grand narrative of the Bible revolves - a presence which starts in Genesis in the Garden of Eden and ends in Revelation in a garden once again.

For Terence Fretheim, focussing on the Old Testament, community forms an integral part of his vision of creation. Earlier in his work he proposed that community in a general sense should be deemed important in that '[a]ll creatures of God together constitute a community in relationship' (Fretheim 2005:269). For him, a holistic approach is needed in which the character of the human being and God, including that of the non-human creature, has to be taken into account in such an approach. Based on a relational model of creation, he envisions all human beings as being 'part of a global community' and therefore they should not be considered as isolated creatures of God (Fretheim 2010:9).

Writing with the same concept in mind, even renowned American poet Wallace Stevens (1957:163) once wrote that '[w] are not our own. Nothing is itself taken alone. Things are because of interrelations and interconnections'. The same sentiment is reiterated by Mbiti (1999:106), who points out that in the context of African traditional life, '[...] the individual does not and cannot exist alone except corporately ... [h] owes his existence to other people ... [h] is simply part of the whole'. Writing from an eco-theological perspective, Moltmann's (1985:17) statement that '[t]here is no such thing as solitary life' undergirds this understanding.

Within the complex inter-relational community that Fretheim describes, three fundamental relational paradigms surface that of dependence, independence and interdependence. The notion of interdependence is brought to the fore in Moltmann's work God in Creation (1985). In dealing with the creatureliness of human beings, Moltmann (1985:186) uses the imago mundi as reference point instead of the imago Dei. Within this paradigm, human beings can only understand themselves in community with all other creatures. Being part of this community, human beings then find themselves in an interdependent relationship with, and dependent on, other creatures, merely a creature amongst many creatures. In contrast to this, Barth sees coexistence as the basic form of what it means to be human. In this sense, it means that humans are human only in relation to God and other human beings (Migliore 2004:105). Migliore (2004:105), affirming the understanding that humans exist 'in a profoundly 
interdependent relationship with the rest of creation', takes Barth's idea of 'human existence-in-coexistence' further by explaining that human existence extends beyond 'the circle of human life'.

Fretheim (2008:n.p.) disagrees with commentators who claim that God works unilaterally by having created the world alone and that he has absolute control over it. He argues that if this was the case, then human beings, having been created in God's image, would understand 'their role regarding the rest of creation in comparable terms - power over, absolute control, and independence' (Fretheim 2008:n.p.). He claims that although creatures are wholly dependent on God for their creation and life, God chooses to 'establish an interdependent relationship with them' in the context of God's originating and continuing creation (Fretheim n.d.). The understanding then is that God does not work in the world from without, but rather works within the world - an approach that is both relational and communal in character.

From a divine perspective, Moltmann (1985:14), by drawing a distinction between one-sided relationships and relationships of mutuality, explains that it is 'the relationships of mutuality that describe a cosmic community of living between God the Spirit and all his created beings'. The relationships of mutuality that speak most to the reality of suffering and pain would be the ones Moltmann identifies as "“sym-pathizing," "participating," "accompanying," [and] "enduring"'. Based on the notion of 'indwelling', one of the relationships of mutuality described by Moltmann, Fretheim's proposal that God does not work unilaterally resonates strongly with Moltmann's (1985:17) work, which is based on a Trinitarian doctrine of creation. For Moltmann (1985) this translates, in the deepest sense, to:

God in the world and the world in God; heaven and earth in the kingdom of God, pervaded by his glory; soul and body united in the life-giving Spirit to a human whole; woman and man in the kingdom of unconditional and unconditioned love, freed to be true and complete human beings. (p. 17)

Approaching the issue from a human perspective, Conniry (2012:22) draws attention to the idea that the ancient Israelites viewed the physical and the spiritual realms 'as dynamically interconnected'. Based on the witnesses of both the Old Testament and the New Testament, he points out that their belief was grounded in the idea that the spiritual realm could be perceived in the same way as humans perceive their physical world - through their five basic senses. He concludes that from a panentheistic perspective, this supports the idea that human beings 'participate in relational union with God by means of [their] embodiedness, not in spite of it' (Conniry 2012:22).

Wegter-McNelly (2011:25-29), reflecting on a whole spectrum of ideas centred around the concept of 'relationality', rightly asks the question of what is meant when contemporary theologians use this term. As 'theological speech about God', and by employing the concept of 'otherness', he points out that the term 'relationality' is often used to evoke 'dynamism and mutuality'. This brings to the fore what he calls 'an opening and welcoming orientation toward "the other" that which "incorporates difference"'. Within the specific context of entanglement, Wegter-McNelly (2011:142) comes to the heart of the matter when he explains that 'the power of an entangled God can be regarded as "plerotic"'. In other words, God's power is a 'self-filling, self-embracing, [and] self-affirming' power that 'grants creation the possibility of relationship and communion through God's entangling presence'. God's entangled, plerotic power is a 'transformative power' that allows 'distinct realities to act in synchrony without ceasing to act independently'.

In terms of 'theological speech about humanity', WegterMcNelly understands 'relationality' as 'the mutuality of "communion"'. This speaks to the proposed idea of mutuality that other scholars, amongst them Moltmann and Fretheim, have incorporated in their work on relationality. In considering the term 'communion', an idea from an unlikely source might be helpful. William Dembski (2014:xiii), well known for his involvement in the intelligent design sphere, believes that 'existence' can be understood in terms of communion, which then translates into communion being defined as the exchange of information. He provides insight by clarifying that when the 'theory of communication' is the focus of attention, it is not particles that are the object of study, but rather different entities between which information is passed. In turn he defines entities by 'their ability to communicate information' (Dembski 2014:xiv). In such an interaction of 'act upon' and 'act', we can also concur with Berger (Berger \& Luckmann [1966] 1991:122) when he states that '[s]ymbolic universes, which proclaim that all reality is humanly meaningful and call upon the entire cosmos to signify the validity of human existence, constitute the furthest reaches of this projection'.

Could one then be so bold as to appropriate Homi K. Babha's terminology for space - 'Thirdspace' - which was conceptualised by Edward Soja to refer to space within a social context in which 'everything comes together ...' (Soja 1996:57) in envisaging the relational, communal space where God and creation 'meet' in communal relationship? Like Wegter-McNelly, Soja refers to the 'other' in his definition of 'Thirdspace', explaining that Thirdspace is '[...] an-Other way of understanding and acting to change the spatiality of human life ...'. Taking up this idea in a broader theological imagining of God indwelling his creation, it provides a potential explication for the relationship between God and creation in terms of creation's 'otherness' (Wegter-McNelly 2011:1).

In bringing all these elements together - the first theologians' understanding of the being of God as 'Being-in-Relation' (Wegter-McNelly 2011:1), Moltmann's proposition of 'relationships of mutuality' and Wegter-McNelly's understanding of 'relationality' as 'the mutuality of "communion"', Dembski's idea that 'to exist is to be in communion, and to be in communion is to exchange 
information' could be considered as a probable binding factor within this proposed Thirdspace, in which God's indwelling would allow for Jesus Christ to relate to the suffering and pain of creation. It is then within this particular Thirdspace where human beings would also be enabled to approach Jesus Christ in prayer and supplication for their needs (Dembski's exchange of information), more so during times of great distress - to make sense of what is happening with and around them, to be saved from disaster, to be healed and to start anew. In response it would be in the same space that Jesus Christ would respond to human beings, and to creation as a whole, in terms of Moltmann's relational interactions and provide for creaturely needs.

\section{Jesus Christ}

The distinctive attribute (cf. Frame 2002:345; Rabie-Boshoff 2016:160-162) 'one-of-a-kind' was identified by RabieBoshoff $(2016: 228,243-244)$ in her study of the first creation story in reference to Jesus Christ in his personal and unique relationship with God. Moreover, in conjunction with this attribute three images - that of 'communicator', 'transformer' and 'partner' - were identified for Jesus Christ in his relation to creation. The image-concept of 'one-of-a-kind partner' is of particular interest to this article, concomitant with the descriptors 'loyal', 'conjoined', 'vulnerable', 'wounded' and 'suffering' (Rabie-Boshoff 2016:228-229). Jesus Christ, in obedience to God, approaches human beings, who live in disobedience to God, to enter into a partnership with them characterised by faith. This one-of-a-kind partnership is characterised on the one hand by Jesus as the one-of-a-kind partner who has all the resources, and on the other hand by humanity, the partner who has no resources - the partner in need.

\section{Jesus Christ: Creation's one-of-a-kind loyal partner}

Instead of employing the term 'partner', Greene (2003:39), in reference to Origen's metaphysics, uses the term 'co-partner' when he identifies Jesus Christ, the Logos, as the Father's copartner. By laying this foundation, Greene builds his argument further by drawing creation and redemption together in the Logos as the Father's co-partner. Greene's (2003) argument is that if:

[T] he Logos as the father's co-partner created out of nothing a world of order, design and beauty, then it was the Logos incarnate as the Father's co-partner, who could save and redeem and so prevent a return to disorder, disintegration and chaos by human sin and evil. (p. 6)

Torrance (2008:116, 117) approaches the subject from a slightly different perspective. He bases his argument on the fuller understanding of 'partnership', and specifically that of covenanted partnership. Basic to his argument is the idea that because Jesus Christ the Son incarnate is utterly dependent on the Father, the relationship between the Son and his human partners can thus be described as a covenanted partnership, in other words a fellowship. Moltmann (1981:25) also takes up the same theme of 'partnership', but instead makes the bold statement that God 'makes God self a partner in a covenant with his people'. Both Torrance and Moltmann's views are in accord with Barth's (1961:50) understanding of human beings being the 'covenanted-partner[s]' of God. In this context Barth calls Jesus Christ the Brother, and God the Father to all human beings (cf. Mk 3:33; Lk 8:21).

In Barth's (1961:33) belief, 'God [is] unique in God's relation to man and the world ...' (cf. McGrath 2008:129). It is this uniqueness that characterises Jesus as 'one-of-a-kind partner', and in particular creation's 'loyal partner', a phrase coined by Barth (1961:36), who identifies God as humankind's 'free partner' in reference to the dialogue, which is initiated by God between God and humankind through Jesus Christ. In this context, Barth (1961:42) then talks about God's 'togetherness' with humankind - a togetherness that identifies God as humankind's 'superior partner'. Polkinghorne (1991:94, 95) uses the term a 'strange togetherness-inseparation', an apt description of the kind of superiority of God's relationship with humankind that reflects both God's revelation and God's hiddenness.

Although Greene's Logos imagery and Torrance's 'Son' imagery contribute significantly in the identification of who Jesus is in relation to creation, it is ultimately Barth's identification of Jesus Christ as 'loyal partner' to God and humankind that encapsulates Jesus' uniqueness as creation's one-of-a-kind loyal partner. This is condensed elegantly in what Barth (1961:64) wrote concerning Jesus: 'Jesus Christ is in His one person, as true God, man's loyal partner, and as true man, God's'. It is as loyal partner to God and humankind that Jesus enters into a relationship of partnering, in other words, a relationship of communion through which 'mercy and love are freely and unreservedly given to humankind' (RabieBoshoff 2016:271). It is through this loyal partnership that Jesus is exposed to the vulnerability of his creation, but ultimately exposes his own vulnerability 'in terms of his creatureliness, sharing his creation's pain, hurt and suffering' (Rabie-Boshoff 2016:271).

Barth (1961:45) refers to Jesus in this one-of-a-kind relationship with creation as the sovereign Lord of the amazing relationship', in which he is both human and divine, both with humankind and different from humankind. Jesus Christ as creation's loyal partner is not only creator of the world and of his human partner, but ultimately in his relationship with God and humankind, which is marked by loyalty, he is creation's redeemer and saviour, ratifying God's image in humankind. Barth (1991) finds the concept of an-/ enhypostasy very appropriate to convey this principle:

The humanity of Christ, although it is body and soul, and an individual, is nothing subsistent or real in itself. Thus it did not exist prior to its union with the Logos. It has no independent existence alongside or apart from him. (p. 157)

In terms of such thinking, Christ is the interface between God and man, as it is in him that God and man meet. Christ's role 
as the interface is also the truth, which is simultaneously the prima, and the ultima, veritas (cf. Barth 1979:26).

\section{Jesus Christ: Creation's one-of-a-kind conjoined partner}

The loyalty of Jesus Christ is of a specific kind - one-of-a-kind loyalty. McFague (2000:31) points out that the assertion that the God of creation and the God of redemption are one and the same God 'is deeply rooted in Hebrew faith'. According to McFague, this assertion 'surfaces in John's incarnational Christology, Paul's cosmic Christ, Irenaeus' notion of Christ recapitulating all of creation, as well as in all the sacramental motifs of Augustine and Thomas'. Macquarrie (1990:48-68) warns, however, that Pauline Christology, by virtue of it being a Christology 'from below', considers 'only the unfolding of the human [creature]'. In the light of this he proposes that a complete Christology is needed to address God's action in everything (Macquarrie 1990:63).

For this reason, it is thus of equal importance to seek an answer to why God assumed flesh as it is to know the human history of Jesus Christ as set out in the New Testament. Historically, Melanchthon considered the same question, asking what good it would do to merely know the history about Jesus Christ unless one knows why he had put on flesh and was nailed to the cross (Pauck 1969:22). More recently, Gregersen (2013:370-393) approached the subject in the way Macquarrie suggested, starting with God by addressing the assertion to which McFague referred to. By doing so, Gregersen (2013:374) situates Jesus Christ within a universal framework and in reference to 1 Corinthians 8:6 and Ephesians 1:4 and 10 explains that the concrete Jesus story is placed in an understanding of God's universal nature and will, while also in the context of heavens and earth'. Gregersen furthermore offers an explanation to the assertion that Jesus Christ is both Creator and Redeemer by pointing out that the basic presupposition of Jesus Christ's relation to God supports the claim that he '... has something to do with the cosmic story' (Gregersen 2013:375). The logical conclusion that flows from this is that the assertion is meaningful that Jesus Christ is 'co-creator' ${ }^{3}$ with the Father and the Spirit from the beginning', and that it can only now be said that " God [is] with us" (Emmanuel), the companion of any creature at any time and place' (cf. McFague 2000:30).

Although this explanation points to Jesus Christ's divine nature and his relationship with God (the Logos - cf. Greene 2003:38, 39), it does not provide an answer as to why God assumed flesh, and more so to God's relation to the world and humankind as the Christ incarnate (the Son - cf. Torrance 2008:116, 117). Gregersen (2013:375) rightly asks the question, '[w]hy did God assume flesh and became [sic] a feature within the picture of the world itself, rather than just remaining its creative frameworker?' Gregersen (2013) supplies the answer himself in reference to the notion of 'deep incarnation', pointing out that the purpose is that of:

$[R]$ econciling humanity with God, and of conjoining God and the world of creation so intensely together that there can be a future also for a material world characterized by decomposition, frailty and suffering. (p. 375)

The notion of 'deep incarnation' thus provides a plausible explanation of how God acts by inserting God-self into the world 'in the creaturely body of Jesus Christ for the purpose of perceiving, communicating and acting in this world' (cf. Macquarrie 1990:409; Rabie-Boshoff 2016:273-274).

This proposition provides a different perspective on the understanding of why God assumed flesh in the person of Jesus Christ. Not only does it highlight Jesus' relation to, and relationship with, the entire created world, but in particular his relation to, and relationship with, humankind. In Gregersen's words, Jesus' relation to creation reaches right down into the roots of biological existence in terms of tolerating, accepting, and incorporating "material existence $\ldots$ in a divine embrace"'. In other words, God acts in Christ on all levels of existence, reaching right down to the 'bottom of the world', the infinitesimal and intricate entangled quantum world, which seems to continually defy human conceptual comprehension (Gregersen 2013:375).

Within the conceptual framework of deep incarnation, Jesus Christ's loyalty as partner to creation is thus not merely superficial at the human level, but extends to all levels of creation, essentially making him the one-of-a-kind partner, and more particularly so the conjoined partner to creation. Peacocke (2007) describes his vision that Jesus, in his full humanity, and his significance to human salvation:

[M] ust share both our evolutionary history and have the same multi-levelled basis for his personhood [... which $]$ means he must be not only flesh of our flesh and bone of our bone, but also DNA of our DNA. (p. 31)

This vision finds remarkable support in, and is expanded in an exceptional way by, Gregersen's (2013:376) argument that 'God conjoins with and for the material world at large as a concretely embodied human person'. Within the radical dimensions of deep incarnation, the law-like and chaotic aspects of creation, which are 'at once anguish-provoking and potentially creative', find expression through Jesus Christ as conjoined partner (Gregersen 2013:375).

\section{Jesus Christ: Creation's one-of-a-kind vulnerable partner}

The notion of vulnerability and the accompanying experiences of suffering and pain is not an often-discussed subject as it brings into focus human weakness and frailty. The vulnerability of creation finds expression in Japanese theologian Kazoh Kitamori's (1916-1998) words: '[...] the world today seems to be stretched out under pain' (Bratcher 1965:153). The worldwide COVID-19 crisis has made this statement come to life in the truest sense of the word and has 
served to bring to light the often-times concealed vulnerability of creation, and human beings in particular. Vulnerability manifests itself in all relationships between humans, relationships between human beings and the natural world, and the relationship between human beings and God. Both physical experiences of suffering and accompanying needs such as safety, hunger and pain amongst others find expression in the first two kinds of relationships, but also including mental needs and experiences such as love, acceptance, grief and more. Biblical evidence attests to the apostle Paul's hardships, mentioned in his first letter to the Corinthian church (1 Cor 4:11-13), which he suffered during his ministry.

Kazoh Kitamori understands God's suffering not only in terms of his wrath in the face of human sin, but also in terms of God's love. For Kitamori, this kind of love is not the same as that which liberal theology attributes to God, which, according to Bauckham (1984:10), '[...] envisages no real obstacle to [God's] immediate love of humanity'. Kitamori believed that God's immediate love of humanity turns to anger because of human sin. In other words, '[God] suffers the conflict of love and wrath within [God-self]' in the face of God's continuous love of humanity (Bauckham 1984:10, 11). Kitamori ultimately came to the conclusion that '[i]n the victory of [God's] love over [God's] wrath [God's] pain mediates [God's] love to sinners' (Bauckham 1984:11).

Placher (1994:xiii), on the other hand, understands divine suffering in the light of God's love for humankind. For Placher the biblical narratives provide a doorway through which the God of love is encountered. This love is described as a love that involves a willingness to put oneself at risk. He believes that God is 'in fact vulnerable in love, vulnerable even to great suffering'.

In the context of God's vulnerability, three challenging ideas concerning Jesus Christ as the self-revelation of God have surfaced in various authors' works - God's homelessness (cf. Dicken 2011), God's weakness (cf. Lienhard 1982) and God's powerlessness (cf. Bonhoeffer 1967). Placher (1994:xii), in reference to Luke 9:58, points out that Jesus Christ's vulnerability is particularly conspicuous in his wandering around with no place to lay his head. In this context, Dicken (2011:127-157) refers to Jesus as the 'Homeless God'. Both homelessness and vulnerability give rise to human powerlessness, which is projected through the image of weakness.

The washing of the disciples' feet (Jn 13:12) is viewed a subversive act by Jesus by which he opens himself up to people, through which his vulnerability becomes discernible (Placher 1994:xiii). The vulnerability of Jesus is indisputable in the event of his suffering and death on the cross, the one event that portrays his weakness and powerlessness in a remarkable way as creation's Suffering Partner.

Jesus' weakness and powerlessness should, however, not be interpreted in terms of a weak and powerless God, but rather in terms of Jesus' humanness and creatureliness. In this regard Placher (1994:16) writes that '[...] the obedient Jesus becomes most fully one with God in increasing human powerlessness'. A perturbing idea is raised by Heyward (1984:28) when she writes that 'Jesus did not come to reveal God's power, God's might, God's victory'. Rather, she says, Jesus came '.. into the pain, the passion, and the wonder of creation itself ... [accepting] the vocation of being truly human in the image of an enigmatic God'.

Lienhard (1982:61) uses a different metaphor when reflecting on Luther's Christology. He sees God appearing at the cross as 'the one who constructs by destroying and who makes alive by killing'. In his reflection, Lienhard, touching on Luther's theology of the cross, points out that Luther often referred to what Paul had written to the Corinthian church concerning the power of the cross (cf. 1 Cor 1:18). In reference to Paul's belief that the power of God is to be found in the seemingly foolish message of the cross, Luther developed his theology around the idea that the power of God is 'hidden in weakness'. Moreover, according to Luther, God's glory becomes manifest in this weakness, and God's wisdom is 'affirmed against all reason' (Lienhard 1982:209).

For Migliore (1991:52), the power of God is a strange power - a power not of force, but the power of the Spirit. One could rightly ask whether it would be fitting to describe this as a one-of-a-kind power. The answer would be yes, seen in the light of God's strange power set against the power of worldly gods. This one-of-a-kind power is a power borne out of a love that transforms the entire world through the event of the cross - it is not the kind of power that is based on power-images of fear, domination and violence. Placher (1994:17) explicates that the kind of love borne out of this power is willing to 'take risks, to care for the other in a way that causes the other's fate to affect one's own, to give to the other at real cost to oneself, to chance rejection'. When Jesus opens himself up, he makes himself vulnerable for the sake of creation and humanity, risking rejection to the extreme. It is through rejection that he then becomes even more vulnerable, weak and powerless. Human nature, on the other hand, seeks power expressly because human beings are afraid of weakness and rejection. Although the human drive for power is borne out of fear to risking vulnerability and thereby facing rejection, Jesus acts out of love, compassion and freedom (cf. Barth 1961:36 - 'man's free partner').

Does Jesus Christ forfeit anything in taking the risk of becoming vulnerable to care for his creation? Barth (1956:177), in reference to God's vulnerability, believes that God does not forfeit anything, but that God is '... capable, and willing, and ready for this condescension'. He describes this as '... an act of extravagance ... [a] far journey' and states that it is this that marks God as the One above all gods. Jesus Christ, as loyal partner to God, identifies fully with God's vulnerability, but as vulnerable partner to creation he forfeits his own creaturely, human life. It is this one-of-a-kind power that is 
expressed through the event of the cross that brings about transformation and that in Paul's words is a saving power for those who are redeemed (cf. 1 Cor 1:18).

\section{Jesus Christ: Creation's one-of-a-kind wounded and hurting partner}

A significant image of Jesus, the loyal partner to God and humankind, is narrated in an old legend from the Talmud, which refers to the Messiah '... sitting among the poor, binding his [own] wounds one at a time, waiting for the time when he will be needed' (Nouwen 1972:81). Four kinds of human 'wounds' are alluded to by Nouwen (1972:83) - alienation, separation, isolation and loneliness - wounds that Bauckham (1984:11) refers to as humankind's 'godforsakenness'. In consideration of these kinds of wounds, it would complete the picture of Jesus' experiences of homelessness, powerlessness and weakness.

The Corinthian church, for example, is reminded by Paul (2 Cor 8:9) that Jesus became poor for their sake so that they may become rich through Jesus' poverty. It is in this state of utmost vulnerability (poor, wounded and hurt) that Jesus offers healing '[...] in terms of forgiveness, justification, regeneration into a new life and ultimately the promise of eternal life and glorification' (Rabie-Boshoff 2016:280). Jesus' woundedness is alluded to in the Old Testament by Isaiah (Is 42:2; 49:7; 50:6). For Nouwen (1972:82), Jesus as the wounded Christ is '[...] the wounded healer, the one who must look after his own wounds but at the same time be prepared to heal the wounds of other'. Jesus as the one-of-a-kind partner (wounded healer) offers healing not only to humankind, but also to the entire creation.

Nouwen (1972:87) suggests that hospitality answers the question of how Jesus' wounds could become the source of healing. Nouwen believes that it encompasses things like 'care and compassion, understanding and forgiveness, fellowship and community'. Jesus does precisely this by offering hospitality to his human partner. Hospitality, as a healing power, requires that 'the host feel[s] at home in his own house, and ... that he [creates] a free and fearless place for the unexpected visitor' (Nouwen 1972:89). Jesus, as partner to his wounded human partner, offers such a one-ofa-kind place - a place where attention and communion are offered, whereby healing is effected for the wounded human partner. God's power is to be found in Jesus' woundedness - a one-of-a-kind power 'that transforms human lives by bringing about healing through forgiveness' (Rabie-Boshoff 2016:281)

\section{Jesus Christ: Creation's one-of-a-kind suffering partner}

A number of prominent scholars, amongst them Luther, Barth, Moltmann and Bonhoeffer, have addressed the issue of a suffering God in their theologies (Bauckham 1984:6-12). It is probably Bonhoeffer (1967:196-197) who has made the most thought-provoking statement with regard to the notion of God's powerlessness, vulnerability and suffering by writing that 'God allows himself to be edged out of the world and onto the cross'. He concludes that it is not because of Christ's omnipotence that he helps us, but it is by his weakness and suffering.

Bonhoeffer (1944:279), having been imprisoned in Tegel Prison for a lengthy period of time, expressed his heartfelt cry on a scrap of paper that 'only the suffering God can help'. According to Simpson (2006:422), a rich metaphor is borne from Bonhoeffer's crucified Christ as the 'suffering God' in terms of God who is 'a God who bears'. Bonhoeffer understood this in terms of ' $[t]$ he Son of God [who] bore our flesh'. For Bonhoeffer, it was not only about Jesus bearing flesh, but also about him bearing the cross. This, in Bonhoeffer's view, constitutes 'incarnation, cross, resurrection, and ascension'. In this context it could then be said that Jesus is "'that kind of Lord," rather than some other kind of lord' - in other words, a one-of-a-kind Lord. Moltmann's vision of the cross, on the other hand, is that it is 'an act of divine solidarity with "the godless and godforsaken"' (cf. Moltmann 1974:276-277). It is into this reality that Jesus enters.

\section{Conclusion}

When creation seemingly shows its 'untamed, wild' face, human beings find themselves virtually at a loss. Apart from their normal daily sense-making activity, which happens mostly subconsciously, they enter into a near 'frenzied' state of mind trying to make sense of what is happening around and to them, and how to respond to this unknown force that is threatening them.

Although science as a valid knowledge base may provide many answers as to possible approaches to natural threats, it does not provide the enduring and satisfying answers that human beings seek during times of suffering and pain. Meylahn (2020:3) affirms the same when he writes about the human response in the time of COVID-19. For Christians in particular, their hope lies in Jesus Christ. The pressing question then is how does Jesus Christ relate to creation, but more so who is he in relation to creation, a creation that is characterised by suffering and pain? The DSL model that was developed by Rabie-Boshoff (2016) for the purpose of her PhD study on the first creation story provides a methodology by which probable answers could be offered as to who Jesus Christ is in relation to creation, especially during times of great duress.

The one image of Jesus Christ as creation's partner was identified concomitant with one significant attribute, one-ofa-kind. Within the context of a suffering creation, Jesus Christ, the suffering partner, identifies with his creation by opening himself up to the pain and suffering of creation, and in particular that of human beings. This, as Bauckham (1984:12) verbalises, with reference to Moltmann's view, is not 'just a revelation of divine sympathy for those who suffer, but an act of divine solidarity with "the godless and godforsaken"' 
(cf. Moltmann 1974:276-277). Jesus Christ as suffering partner enters into this godless and godforsaken reality. God could only suffer in the way he did on the cross as the godforsaken man Jesus, and as Father of the godforsaken man Jesus (Bauckham 1984:12).

The metaphors of 'the suffering Jesus as the Son of God who bore both flesh and the cross before death', and 'the suffering God who bore the pain of knowing the loss of a son unto death' (Rabie-Boshoff 2016:283-284), are powerful in gaining understanding of who Jesus Christ is as creation's suffering partner, but more so as loyal partner to God and humanity (Barth) and on a much deeper (quantum) level as creation's conjoined partner (Gregersen).

When the University of Pretoria bestowed an honorary doctorate during the Faculty of Theology's centennial in 2017 to Moltmann, he left to the newly graduates in his acknowledgement address the following consoling message (Moltmann et al. 2017):

Our task is to begin something new; God's task is to complete, to set right, and to heal what we humans - all too humanly - have begun. In this trust we can go over our limits: 'Think big'. In this hope we can leave behind our traditions and try to create something greater: 'Oopmaak van die hekke ...'. (p. 4)

This challenge centres on Jesus Christ's relevance, in terms of his identity, for Christians in particular, but also for creation as a whole. Moltmann (1985:36) says it very aptly in the original: 'Here we shall take a different approach, and shall pursue the model of identity and relevance. The identity of the Christian belief in creation has become questionable in today's ecological crisis and must therefore be given a new definition in that context; while the relevance of belief in creation must prove itself in ideas about the present ecological crisis and in suggested ways from that crisis'.

\section{Acknowledgements Competing interests}

The authors declare that they have no financial or personal relationships that may have inappropriately influenced them in writing this research article.

\section{Authors' contributions}

The article is based on a $\mathrm{PhD}$ dissertation by A.C.R.B. under the supervision of J.B. The article is a development and application of the thesis and augmented by J.B.

\section{Ethical considerations}

This article followed all ethical standards for research without direct contact with human or animal subjects.

\section{Funding information}

This research received no specific grant from any funding agency in the public, commercial or not-for-profit sectors.

\section{Data availability statement}

Data sharing is not applicable to this article as no new data were created or analysed in this study.

\section{Disclaimer}

The views and opinions expressed in this article are those of the authors and do not necessarily reflect the official policy or position of any affiliated agency of the authors.

\section{References}

Barth, K., 1956, Church dogmatics, Volume 4, The Doctrine of Reconciliation, Part 1 transl. G.W. Bromiley \& T.F. Torrance, Bloomsbury Publishing, London.

Barth, K., 1961, The humanity of God, Collins (The Fontana Library of Theology and Philosophy), London.

Barth, K., 1979, Dogmatics in outline, transl. G.T. Thomson, SCM Press, London.

Barth, K., 1991, The Göttingen dogmatics, vol. I, transl. G.W. Bromiley, Eerdmans, Grand Rapids, MI.

Bauckham, R., 1984, “'Only the suffering God can help": Divine passibility in modern theology', Themelios 9(3), 6-12.

Berger, P. \& Luckmann, T., [1966] 1991, The social construction of reality, Penguin Books, London.

Bonhoeffer, D., 1944, Letter to Eberhard Betge, 30 Apr 1944, LPP, London.

Bonhoeffer, D., 1967, Letters and papers from prison, SCM Press, London.

Bratcher, M.E. (transl.), 1965, Theology of the pain of God: The first original theology from Japan, John Knox Press, Richmond.

Buitendag, J., 2009, 'Nature as creation from an eco-hermeneutical perspective: From a "natural theology" to a "theology of nature"', HTS Teologiese Studies/Theological Studies 65(1), Art. \#272. https://doi.org/10.4102/hts.v65i1.272

Collicutt, J., 2008, 'Discernment and the psychology of perception', in A.E. McGrath (ed.), The open secret: The renewal of natural theology, pp. 80-110, Blackwell Publishing, Oxford.

Conniry, C.J., 2012, 'Participation in God', Relational Theology, Faculty Publications, Portland, viewed 16 April 2020, from https://digitalcommons.georgefox.edu/cgi/ viewcontent.cgi?article=1023\&context=gfes.

Dembski, W.A., 2014, Being as communion: A metaphysics of information, Routledge, New York, NY.

De Wet, C.L., 2020, 'Is illness God's punishment? Theological perspectives from the Bible and the Apocrypha', LitNet (Academic), viewed 13 May 2020, from https:// www.litnet.co.za/is-illness-gods-punishment-theological-perspectives-from-thebible-and-the-apocrypha/.

Dicken, T.M., 2011, 'The homeless God', The Journal of Religion 91(2), 127-157. https://doi.org/10.1086/658106

Duvall, J.S. \& Hays, J.D., 2019, God's relational presence: The cohesive Center of Biblical Theology, Baker Academic, Ada.

Frame, J.M., 2002, The Doctrine of God, P\&R Publishing, Phillipsburg, NJ.

Fretheim, T., 2005, God and the world in the Old Testament: A relational theology of creation, Abingdon Press, Nashville, TN.

Fretheim, T., 2008, Commentary on Genesis 1:1 - 2:4a, viewed 12 April 2020, from https://www.workingpreacher.org/preaching.aspx?commentary_id=78.

Fretheim, T., 2010, Creation untamed: The Bible, God, and natural disasters, Baker Academic, Grand Rapids, MI.

Fretheim, T., n.d., Creation in community, viewed 12 April 2020, from https://www. ctsnet.edu/at-this-point/creation-community-faith-environment/.

Gilkey, L., 1993, Nature, reality, and the sacred: The nexus of science and religion, Fortress Press, Minneapolis, MN.

Greene, C.J.D., 2003, Christology in cultural perspective: Marking out the horizons, William B. Eerdmans, Grand Rapids, MI.

Gregersen, N.H., 2000, 'Varieties of personhood: Mapping the issues', in N.H. Gregersen, W.H. Drees \& U. Görman (eds.), The human person in science and theology, pp. 1-17, T \& T Clark, Oxford.

Gregersen, N.H., 2013, 'Cur deus caro: Jesus and the cosmos story', Theology and Science 11(4), 370-393. https://doi.org/10.1080/14746700.2013.836891

Hefner, P., 1993, The human factor: Evolution, culture, and religion, Fortress Press, Minneapolis, MN

Hefner, P., 2006, 'Religion-and-science', in P. Clayton \& Z. Simpson (eds.), The Oxford handbook of religion and science, pp. 562-567, Oxford University Press, Oxford.

Heyward, I.C., 1984, Our passion for justice: Images of power, sexuality and liberation, Pilgrim Press, New York, NY.

James, W., 1956, The will to believe, Dover Publications, New York, NY.

Kaufman, G.D., 2000, 'Ecological consciousness and the symbol "God"', BuddhistChristian Studies 20(1), 3-22. https://doi.org/10.1353/bcs.2000.0012 
Laudisa, F. \& Rovelli, C., 2013, 'Relational quantum mechanics', in E.N. Zalta (ed.), The Stanford encyclopedia of philosophy, viewed 27 August 2015, from http://plato. Stanford encyclopedia of philosophy, viewed 27 August
stanford.edu/archives/sum2013/entries/qm-relational/.

Lienhard, M., 1982, Luther: Witness to Jesus Christ, transl. E.H. Robertson, Augsburg Publishing House, Minneapolis, MN.

Macquarrie, J., 1990, Jesus Christ in modern thought, SCM Press, London.

Mbiti, J.S., 1999, African religion and philosophy, Heinemann, Oxford.

McFague, S., 2000, 'An ecological Christology: Does Christianity have it?', in D.T. Hessel \& R.R. Ruether (eds.), Christianity and ecology: Seeking the well-being of earth and humans, pp. 29-45, Harvard University Press, Cambridge, MA.

McGrath, A., 2008, The open secret: A new vision for natural theology, Blackwell Publishing, Oxford.

McGrath, A., 2009, A fine-tuned universe: The quest for God in science and theology, Westminster John Knox Press, Louisville, KY.

McGrath, A., 2011, Surprised by meaning: Science, faith, and how we make sense of things, Westminster John Knox Press, Louisville, KY.

Meylahn, J.-A., 2020, 'Being human in the time of Covid-19', HTS Teologiese Studies/ Theological Studies 76(1), a6029. https://doi.org/10.4102/hts.v76i1.6029

Migliore, D.L., 1991, Faith seeking understanding, William B. Eerdmans, Grand Rapids, MI.

Migliore, D.L., 2004, Faith seeking understanding, William B. Eerdmans, Grand Rapids, MI.

Moltmann, J., 1974, The crucified God: The cross of Christ as the foundation and Criticism of Christian theology, transl. R.A. Wilson \& J. Bowden, SCM Press, London.

Moltmann, J., 1981, The trinity and the Kingdom of God: The Doctrine of God, transl. R.A. Wilson \& J. Bowden, SCM Press, London.

Moltmann, J., 1985, God in creation: A new theology of creation and the spirit of God, The Gifford lectures 1984-1985, transl. M. Kohl, Fortress Press, Minneapolis, MN.
Moltmann, J., Tveit, O.F., Nürnberger, K. \& Buitendag, J., 2017, 'Tribute, hope and reconciliation', HTS Teologiese Studies/Theological Studies 73(1), a4724. https:// doi.org/10.4102/hts.v73i1.4724

Nouwen, H.J.M., 1972, The wounded healer, Image Books, Garden City, NY.

Pauck, W. (ed.) 1969, Melanchthon and Bucer, SCM Press, London.

Peacocke, A., 1984, Intimations of reality: Critical realism in science and religion, Notre Dame University Press, Notre Dame, IN.

Peacocke, A., 2007, All that is: A naturalistic faith for the twenty-first century, P. Clayton (ed.), Fortress Press, Minneapolis, MN.

Placher, W.C., 1994, Narratives of a vulnerable God: Christ, theology, and scripture, Westminster John Knox Press, Louisville, KY.

Polanyi, M., 1967, The tacit dimension, Doubleday, Garden City, NY.

Polkinghorne, J.C., 1991, Reason and reality: The relationship between science and theology, Society for Promoting Christian Knowledge, London.

Rabie-Boshoff, A.C., 2016, 'Seeing God's voice in creation; A visio-spatial interpretation of Genesis 1', PhD thesis, University of Pretoria.

Schaeffer, F.A., 1972, Genesis in space and time, InterVarsity Press, Downers Grove, IL.

Simpson, G.M., 2006, '“God is a God who bears": Bonhoeffer for a flat world', Word \& World 26(4), 419-428.

Solms, M. \& Turnbull, O., 2002, The brain and the inner world: An introduction to the neuroscience of subjective experience, Karnac Books, London.

Stevens, W., 1957, Opus posthumous, S.F. Morris (ed.), Alfred A. Knopf, New York, NY. Soja, E.W., 1996, Thirdspace, Blackwell, Malden, MA.

Torrance, T.F., 2008, Incarnation: The Person and life of Christ, R.T. Walker (ed.), InterVarsity Press, Downers Grove, IL.

Walton, J.H., 2009, The lost world of Genesis one: Ancient cosmology and the origins debate, InterVarsity Press, Downers Grove, IL.

Wegter-McNelly, K., 2011, The entangled God: Divine relationship and quantum physics, Routledge, New York, NY. 